\title{
KEEFEKTIFAN STRATEGI VISUAL DALAM PEMBELAJARAN KETERAMPILAN SOSIAL PADA ANAK DENGAN KONDISI SPEKTRUM AUTIS TIPE SINDROMA ASPERGER (ASD)
}

\author{
Wawan', Anna ${ }^{2}$ \\ ${ }^{1}$ Dosen Poltekkes Kemenkes Surakarta Jurusan Okupasi Terapi, \\ ${ }^{2}$ Okupasi Terapis TPP A1 Firdaus Surakarta \\ Email: abiroyyan_naufal@yahoo.co.id
}

\begin{abstract}
Abstrack: Effectiveness Visual Strategy in Social Skills Learning in Children with Spectrum Condition of Autism Asperger's Syndrome (ASD). Tantrum behavior is a behavior that often appears in children with autism spectrum, in the form of behavioral tantrums, anger outbursts, screams, cries, banging his head, banging, kicking, rolling and rigidity of the body. It often makes teachers and parents are confused about it. This research was descriptive qualitative analytic. Sampling was done by sampling techniques with specific criteria (purposive sampling). Informants in this study is a teacher assistant (shadow teacher), parents and classroom teachers. The results showed that (1) the planning of learning social skills with visual strategy was well planned but tems still general, (2) the implementation of learning social skills with visual strategy done in the classroom and outside the classroom, using the drawings concerning a actions to be performed by children, (3) evaluation of learning social skills with visual strategies have been implemented during the learning process and at the end of the study, but has not been well documented, (4) the use of visual strategies in learning social skills in children ASD types Asperger syndrome rated very effective views of a significant change in behavior before and after learning social skills with visual strategy. The implications of this study that the TPP Al-Firdaus need to use visual strategies in learning social skills in autistic children and improve the quality of teachers and therapists to use visual strategies for learning and therapy for children with autism more optimal
\end{abstract}

Keywords: Visual strategy, Learning social skills, Autism Spectrum Disorder (ASD)

\begin{abstract}
Abstrak: Kefektifan Strategi Visual dalam Pembelajaran Keterampilan Sosial pada Anak dengan Kondisi Spektrum Autis Tipe Sindroma Asperger (ASD). Perilaku tantrum merupakan perilaku yang sering muncul pada anak spektrum autisme, berupa perilaku mengamuk, amarah meledak-ledak, jeritan, tangisan, membentur-benturkan kepala, memukul-mukul, menendang, berguling-guling dan kekakuan tubuh. Penelitian ini bertujuan untuk mengetahui efektifitas penerapan strategi visual untuk mengatasi perilaku tantrum pada anak dengan kondisi Autis Spectrum Disorder (ASD). Penelitian ini termasuk penelitian deskriptif analitik kualitatif. Pengambilan sampel dilakukan dengan teknik sampling dengan kriteria tertentu (purposive sampling). Informan dalam penelitian ini adalah guru pendamping (shadow teacher), orang tua dan guru kelas. Hasil penelitian menunjukkan bahwa (1) perencanaan pembelajaran keterampilan sosial dengan strategi visual sudah terencana dengan baik tetapi sistem pendokumentasian masih bersifat umum, (2) pelaksanaan pembelajaran keterampilan sosial dengan strategi visual dilakukan di dalam kelas dan luar kelas, dengan menggunakan gambar-gambar mengenai suatu tindakan yang harus dilakukan oleh anak, (3) evaluasi pembelajaran keterampilan sosial dengan strategi visual sudah dilaksanakan selama proses pembelajaran maupun di akhir pembelajaran, namun belum terdokumentasi dengan baik, (4) penggunaan strategi visual dalam pembelajaran keterampilan sosial pada anak ASD tipe Sindroma Asperger dinilai sangat efektif dilihat dari perubahan perilaku yang signifikan sebelum dan sesudah diberikan pembelajaran keterampilan sosial dengan strategi visual. Implikasi penelitian ini bahwa TPP Al Firdaus perlu menggunakan strategi visual dalam pembelajaran keterampilan sosial pada anak autis serta meningkatkan kualitas guru dan terapis agar penggunaan strategi visual dalam pembelajaran dan terapi untuk anak autis lebih optimal
\end{abstract}

Kata Kunci: Strategi visual, Pembelajaran keterampilan sosial, Autis Spectrum Disorder (ASD)

Komunikasi mempunyai peranan yang sangat penting dalam kehidupan seseorang, sehingga komunikasi harus dimulai sedini mungkin, bahkan ketika anak masih dalam kandungan. Komunikasi melibatkan beberapa proses, yaitu pendengaran, pikiran, pengertian, 
kemauan, dan kebutuhan berkomunikasi. Namun, terkadang hal itu sulit terjadi pada anak-anak tertentu, seperti pada anak autisme, anak dengan inteligensi sangat rendah, anak hiperaktif, anak tunarungu, dan lain-lain.

Autisme saat ini menjadi momok bagi banyak orang tua. Mungkin karena jumlah angka kejadiannya yang terus meningkat diseluruh dunia. Namun di Indonesia sendiri, belum ada data yang menunjukkan secara pasti besarnya angka kejadian tersebut. Survey data dari California Department of Developmental Service, Amerika Serikat (AS), melaporkan bahwa sampai Januari 2003, telah terjadi peningkatan kasus anak yang menderita autisme di Amerika Serikat sampai 31\%. Ikatan Dokter Anak AS dan Pusat Kontrol dan Pencegahan Penyakit AS bahkan menambahkan bahwa jumlah anak yang didiagnosis menderita autisme sekitar 1:166 anak. Padahal, 10 tahun yang lalu, angka kejadiannya hanya 1:2500 anak

Di Taman Pendidikan Al Firdaus sebagai sekolah yang melaksanakan program inklusi pada tahun ajaran 2011-2012 terdapat 2 orang anak dengan kondisi autis tipe asperger. Satu anak ada di playgroup dan satu anak ada di kelas B.

Pembelajaran untuk kedua anak ini berlangsung bersama dengan anak reguler yang lain namun mereka mendapatkan dukungan program khusus dari Puspa (Pusat Pelayanan Anak Berkebutuhan Khusus) Al Firdaus. Program khusus yang diberikan berupa pendampingan oleh satu guru untuk satu anak dan juga pemberian terapi sesuai dengan kebutuhannya.

Kedua anak ini kurang mampu untuk bertindak seperti layaknya anak-anak yang lain. Berdasarkan informasi orang tua dari salah satu anak didapatkan data bahwa anak sangat sulit diajak pergi ke supermarket/ mall. Aktifitas belanja di mall yang seharusnya bisa dijadikan rekreasi berubah menjadi sesuatu yang tidak menyenangkan sehingga terkadang membuat orang tua kesulitan.

Untuk mengatasi hal tersebut, orang tua berusaha memberikan penjelasan secara lisan kepada anak, tetapi hasil yang diperoleh, anak tetap ingin terus naik dan turun eskalator dan sulit untuk dikendalikan.

Berdasarkan kejadian tersebut, terapis mencoba mencari akar permasalahannya mengapa anak tidak mau mengikuti penjelasan lisan yang diberikan. Setelah dikaji lebih lanjut, akhirnya ditemukan dugaan bahwa kemungkinan permasalahan ini timbul karena adanya komunikasi yang terputus. Komunikasi yang terputus adalah akar masalah sosial, pendidikan dan perilaku anak.

Untuk mengatasi masalah tersebut dipilih program pembelajaran dengan menggunakan strategi visual, hal ini dipilih sebagai alternatif solusi mengatasi perilaku anak. Berdasarkan latar belakang tersebut, penulis tertarik untuk mengetahui lebih jauh tentang keefektififan strategi visual dalam pembelajaran keterampilan sosial pada Anak dengan Kondisi Spektrum Autisme (Sindroma Asperger).

\section{METODE PENELITIAN}

\section{Tempat dan Waktu Penelitian}

Penelitian ini dilakukan di Taman Pendidikan Prasekolah (TPP) Al Firdaus Surakarta, dilakukan pada bulan Desember 2011 sampai April 2012.

\section{Bentuk Penelitian}

Penelitian ini merupakan penelitian deskriptif analitik kualitatif untuk menjawab "mengapa" dan "bagaimana", yakni lebih menggali data dan informasi (eksplorasi) sehingga dapat diketahui pendapat dan pandangan guru, orang tua dan terapis.

\section{Strategi Penelitian}

Terarah pada satu karakteristik dalam satu bidang ilmu yaitu ilmu perilaku khususnya keterampilan sosial. Tujuan dan maksud dilakukannya penelitian ini adalah untuk mengadakan analisis, maka penelitian ini digolongkan dalam penelitian evaluasi. Kegiatan yang akan dievaluasi adalah kegiatan pembelajaran keterampilan sosial dengan strategi visual. Permasalahan dan fokus penelitian dalam penelitian sudah ditentukan sebelumnya yaitu studi kasus terpancang.

\section{Sumber Data}

Sumber data penelitian ini adalah Informan, terdiri dari Guru TPP Al Firdaus Surakarta, Orang tua siswa, terapis, serta arsip dan dokumen mengenai pembelajaran keterampilan sosial, terdiri dari perencanaan, pelaksanaan dan evaluasi.

\section{Tehnik Pengumpulan Data}

Pengumpulan data dilakukan dengan cara wawancara mendalam pada kelompok guru, orang tua dan terapis sebagai informan. Focus group discussion/FGD dilakukan dengan cara diskusi dengan beberapa guru dan terapis yang berjumlah minimal tiga orang. Peserta diskusi 
diacak sehingga bukan bagian dari informan wawancara. Observasi lapangan dilakukan untuk menilai jalannya pembelajaran keterampilan sosial secara langsung. Peneliti terjun bersama dengan guru untuk melaksanakan pembelajaran keterampilan sosial.

\section{Subyek dan Obyek Penelitian}

Subyek penelitian ini adalah guru, orang tua dan terapis berjumlah lebih dari 3 orang. Sedangkan obyek dalam penelitian ini adalah anak dengan kondisi spektrum autisme tipe asperger.

\section{Keabsahan Data}

Untuk keabsahan data dilakukan dengan triangulasi, yaitu sumber data mengenai perencanaan, pelaksanaan dan evaluasi pembelajaran dari sumber guru, dibandingkan dengan sumber orang tua dan terapis. Triangulasi metode dilakukan dengan cara pengumpulan data mengenai perencanaan, pelaksanaan dan evaluasi pembelajaran melalui metode wawancara, FGD dan metode lain.

\section{Analisis Data}

Dilakukan pada saat pengumpulan data berlangsung dan setelah selesai pengumpulan data dalam periode tertentu. Pada saat wawancara, peneliti sudah melakukan analisis terhadap jawaban yang diwawancarai. Bila jawaban yang diwawancarai setelah dianalisis terasa kurang memuaskan, maka peneliti akan melanjutkan pertanyaan lagi sampai tahap tertentu diperoleh data yang dianggap kredibel.

\section{HASIL}

\section{Perencanaan Pembelajaran Keterampilan Sosial}

Perencanaan pembelajaran keterampilan sosial dengan strategi visual pada anak autis sindroma asperger sudah terstruktur dan sistematis.

\section{Pelaksanaan Pembelajaran Keterampilan Sosial}

Pelaksanaan pembelajaran ketrampilan sosial dengan strategi visual dirasakan cukup efektif.

\section{Evaluasi Pembelajaran Keterampilan Sosial}

Sudah melaksanakan evaluasi, yaitu:

1. Evaluasi selama proses kegiatan pembelajaran keterampilan sosial dengan langsung memberi tahu anak kalau ada yang salah
2. Melalui pengamatan secara individual dan sambil bermain

3. Menjelang laporan akhir semester

4. Praktek langsung tidak secara pribadi

5. Orang tua melakukan evaluasi berdasarkan perubahan perilaku anak ketika berada pada situasi yang nyata

Pada evaluasi, tidak ditemukan lembar evaluasi yang khusus menilai hasil pembelajaran keterampilan sosial yang diajarkan

\section{Temuan Lain}

Dalam penelitian terungkap beberapa kendala pelaksanaan strategi visual, yaitu:

1. Kurangnya kontak mata anak ketika diperlihatkan gambar-gambar.

2. Kesulitan mengungkap pesan keterampilan dalam suatu obyek gambar.

3. Adanya orang tua dan lingkungan yang kurang memahami tentang kondisi anak.

4. Kesulitan mendapatkan gambar yang sesuai untuk mendukung strategi visual yang diberikan.

5. Penyampaian kalimat yang mendukung strategi visual yang diberikan.

\section{PEMBAHASAN}

\section{Perencanaan Pembelajaran}

Perencanaan pembelajaran merupakan tahap pre-active (Hasibuan \& Moejono: 38). Dalam pembelajaran keterampilan social dengan strategi visual maka perencanaan dilakukan dengan melakukan observasi terhadap kondisi anak. Perencanaan dengan cara menyiapkan gambar-gambar yang akan digunakan dan perencanaan merupakan pelaksanaan kurikulum.

\section{Pelaksanaan Pembelajaran}

Pelaksanaan pembelajaran ketrampilan sosial sudah baik, dilakukan di luar dan di dalam kelas. Dalam tahap pelaksanaan pembelajaran disesuaikan dengan metode yang sesuai dengan siswa (Conner, 1980: 12). Di lapangan akan ditemukan bahwa terkadang dalam pelaksanaan ada yang langsung berhasil, namun ada juga yang berulang-ulang diberikan. Metode strategi visual juga merupakan metode yang sangat efektif untuk menolong anak berkebutuhan khusus, khususnya anak dengan kondisi autis dalam memahami suatu perilaku dalam berinteraksi. Karena sebagian besar anak autis adalah pembelajar dengan visual (Linda Hadgdon, 2007: 1-2). Pada pelaksanaan/ implementasi pembelajaran, perlu dikembangkan strategi instruksional dan bahan intstruksional yang 
sesuai dengan karakteristik peserta didik (Dick and Carey, 1990: 163).

\section{Evaluasi Pembelajaran}

Hasil penelitian menunjukkan bahwa evaluasi sudah dilaksanakan selama proses pembelajaran dan diakhir program pembelajaran. Evaluasi belajar adalah proses penentuan perolehan belajar berdasarkan kriteria tertentu. Penentuan hasil belajar dapat dilakukan dengan pengukuran, perbandingan, penilaian dan kemudian keputusan hasil penilaian (Gronlund, 1985: 57).

\section{SIMPULAN}

Kesimpulan penelitian ini adalah pembelajaran keterampilan sosial dengan strategi visual cukup efektif. Perencanaan pembelajaran keterampilan sosial dengan strategi visual sudah dilakukan dengan cara observasi perilaku di sekolah, rumah dan luar rumah. Selanjutnya disusun gambar sesuai perilaku yang akan diajarkan. Pelaksanaan strategi visual sudah dilakukan dengan baik dengan memberikan materi keterampilan sosial dalam bentuk gambar yang sederhana dan dijelaskan kepada anak dengan menggunakan bahasa yang sederhana dan

\section{DAFTAR PUSTAKA}

Anonim. Sindrom Asperger. 2007. Diunduh tanggal 27 November 2011 dari http//ms. wikipedia.org

Atwi Suparman. 1997. Desain Instruksional: Bahan Ajar Program Pengembangan Keterampilan Dasar Teknik Instruksional Untuk Dosen Muda. Jakarta : PAU Departemen Pendidikan dan Kebudayaan.

Camphell,L. 1996. Teaching and Learning Through Multiple Intelligence. Massachusset: A Simin and Schuster Company.

Conner,R.D. 1998. Gathering Information about Teacher Classroom Behaviour. Makalah: Tidak dipublikasikan.

Dick, Walter, dan Lou Carey. 1990. The Systematic Design of Instruction. Third Edition. Florida : Harpe Collins Publisher.

Greenspan,S \&Wieder.S. 2010. "Engaging Autism" Melangkah Bersama Autisme. Jakarta: Yayasan Ayo Main.

Groundland, Norman E. 1985. Measurement and Evaluation in Teaching. New York: Mc Milan Publishing Company EGC. tepat. Evaluasi pembelajaran keterampilan sosial dengan strategi visual sudah dilakukan dengan cara melakukan observasi di sekolah, rumah dan lingkungan terhadap perilaku anak yang telah diprogramkan, tetapi belum terdokumentasi dengan baik.

Saran untuk orang tua selalu menggunakan strategi visual dalam mengajarkan keterampilan sosial pada anak autis, memberikan kesempatan untuk mempraktekan keterampilan sosial yang sudah dikuasai anak serta menjalin kerja sama dengan sekolah untuk mendukung keberhasilan anak. Untuk TPP Al Firdaus, sebaiknya menggunakan strategi visual dalam pembelajaran keterampilan sosial kepada anak autis, memberikan bekal kepada para guru reguler, tidak hanya guru pendamping khusus atau terapis untuk menggunakan strategi visual dalam pembelajaran terhadap anak autis. Untuk guru dan terapis, sebaiknya mendokumentasikan semua hal yang berhubungan dengan program strategi visual yang dilakukan, kreatif dan inovatif dalam menggunakan media strategi visual, dan memberikan strategi visual tidak hanya terhadap anak autis saja namun juga pada ABK yang lain maupun anak kelas regular

Hadgdon, L. 2007. 25 Reason to Use Visual Strategy. Diunduh tanggal 21 November 2011 dari www.usevisualstrategies.com/

Hasibuan dan Moedjiono. 2000. Proses Belajar Mengajar. Bandung: PT Remaja Rosdakarya.

Hidayat. 2006. Mengenal Autisme dan Pendidikannya. Makalah Pelatihan di BPG SLB Bandung.

Hidayat. 2006. Strategi Visual untuk Peningkatan Komunikasi dan Atensi-Kosentrasi Anak Autis.Makalah Pelatihan di BPG SLB Bandung.

Kresno Sudarti, Ella NH., Endah W., dan Iwan A. 2000. Aplikasi Metode Kualitatif dalam Penelitian Bidang Kesehatan. Jakarta : Fakultas Kesehatan Masyarakat UI.

Mc Partland, J \& Klin, A. 2006. Asperger's Sydrome. Adolescent Medical Clinic. 17 (3): 71-88 dalam http//ms. Wikipedia.org

Meyer, R.E. 2007. Learning. Jounal of Wikipedia the free encyclopedia. Diunduh tanggal 21 Januari 2012 Dari. http//en.wikipedia.org

Pusponegoro, H.D. 2005. Autisme, Bagaimana mengenalnya? Anakku.1.10-14. 
Sutopo HB. 2006. Metodologi Penelitian Kualitatif: Dasar Teori dan Terapannya dalam Penelitian. Surakarta: UNS Press.

Slameto. 2003. Belajar dan Faktor-faktor Yang Mempengaruhinya. Jakarta: PT Rineka Cipta.

Sugiyono. 2005. Memahami Penelitian Kualitatif. Bandung: Alfabeta
Utami,S. 2001. Menangani Perilaku Pada Anak Autistik di Sekolah. Nikita. Jakarta: PT. Gramedia.

Williams,R. 2009. Visual Learning Theory. Diunduh tanggal 21 Januari 2012. Dari http://www.aweoregon.org/research_theor y.html 